\title{
Hunger, food security and welfare policies: issues and debates in First World societies*
}

\section{BY GRAHAM RICHES}

\author{
Social Work Programme, Faculty of Health and Human Sciences, University of Northern British \\ Columbia, 3333 University Way, Prince George, British Columbia V2N 4Z9, Canada
}

The present paper explores the relationship between hunger, food security and welfare policies in a number of First World societies. It asks what we know about the incidence and nature of hunger in advanced industrial countries, examines its causes and the ways in which hunger has been responded to by the state and civil society, and in light of current debates about welfare reform, asks what should be done to establish the right to food security.

The present paper draws on comparative research, based on national case studies, examining the growth of hunger and absolute poverty in the last two decades of the twentieth century in five advanced 'liberal' welfare states: Australia, Canada, New Zealand, UK and USA. In such welfare states, following Esping-Andersen (1990), people's entitlements to welfare assistance are directly related to their capacity to sell their labour power in the market place. In this sense their social rights, such as the right to adequate income support and food, are commodified. Such rights are not inherent, nor inalienable. The essential premise of this study is that hunger is a basic human need and that food security is a fundamental human right: in other words hunger is primarily a matter of distributive justice and a political question which should be accorded the highest priority by both the state and civil society.

The perplexing question, just 3 years from the dawn of the twenty-first century, is why hunger should be a growing, yet publicly neglected, health and welfare issue in wealthy and technologically-advanced countries which in aggregate terms are food secure and which historically have well-developed social safety nets which, in recent years, have been subjected to welfare reforms ostensibly directed at targeting benefits to those in greatest hardship. Moreover, not only is hunger economically inefficient, its continued existence violates domestic welfare legislation and the international human rights obligations of First World countries. Indeed, the accumulating evidence would suggest that hunger in wealthy industrial societies has become depoliticized as a public policy issue with profound personal, health, social and moral consequences not just for those in need but for society as a whole.

Why is it that in the wake of the World Declaration on Nutrition (Food and Agriculture Organization, 1992) and the World Summit for Social Development (United Nations, 1995a) and in the run up to the World Food Summit in Rome in November 1996 the main emphasis of countries such as Canada and the United States is on the establishment of food security in developing countries? In light of the evidence that these countries, as well as New Zealand and UK, as a result of welfare reform have undermined their social safety nets, including rights to adequate financial assistance, a nagging question remains about the nature of their First World prescriptions for advancing food security beyond their shores. In conclusion, the present paper will explore the question of what needs to be done to ensure that 'liberal' welfare states can break their mould and establish the right to food security.

\footnotetext{
*This paper is adapted from Chapters 1 and 7 in Riches, G. (Editor) (1997). First World Hunger: Food Security and Welfare Politics. London: Macmillan.
} 


\section{HUNGER AND FOOD SECURITY IN ADVANCED INDUSTRIAL SOCIETIES}

Hunger, of course, is not a new issue, but in recent years it has become more pronounced as a health and welfare issue in the affluent 'North' or 'West'. Only in the USA, as Poppendieck (1997) has noted, has hunger been on the political agenda for the last 60 years, although in Canada, Australia, New Zealand and UK it is now being rediscovered. Like poverty, hunger is a difficult concept to define, but in the context of advanced industrial societies it is perhaps first necessary to consider possible objections to using the term. Clearly one should distinguish First World hunger from the starvation and malnutrition brought about by famine and endemic undernourishment in developing countries (Dreze \& Sen, 1989) where it is estimated that in 1990 nearly 800 million people, or $20 \%$ of the developing world's population, were chronically undernourished (Bread for the World Institute, 1995). Yet hunger and undernutrition caused by lack of access to food is a growing phenomenon in affluent First World countries, certainly not on the scale that exists in developing countries, but its prevalence is a major public policy issue.

It may even appear to be highly contradictory to be writing about hunger in wealthy industrial societies when, as Dreze \& Sen (1989) have noted, 'the typical person in Europe or North America tries to reduce-rather than increase-calorie intake'. In other words over-consumption and the specialized diets needed to contain it vie with hunger as a health and social issue.

A key issue is that governments of advanced industrial nations refuse to acknowledge the existence of hunger. They are assisted in their denial when, for example, the United Nations Development Programme (UNDP; United Nations, 1994) reports on the problem of global poverty without providing data on hunger and poverty in industrial countries. The UNDP ranks the countries of the world according to their socio-economic progress and uses a human development index (HDI) which is a more comprehensive measure than gross national product. Its key indicators are longevity (increases in life expectancy), knowledge (advances in literacy and mean years of schooling) and standard of living (as measured by purchasing power; United Nations, 1994). Yet while data on absolute poverty are included for developing countries, there is no mention of the incidence of poverty in the industrial world, although data are provided on unemployment and income distribution. In 1994, Canada came first of fifty-three 'high development countries' on the HDI index. Australia and the USA were seventh and eighth, and the UK and New Zealand ranked tenth and eighteenth respectively (United Nations, 1994). The troubling fact is that each of these countries confronts significant issues of hunger and poverty.

Three approaches to understanding the concept of hunger are suggested: hunger as a key element of absolute poverty and significant consequence of relative deprivation; hunger and its relationship to the broader question of food security and healthy well-being; hunger understood as a political problem and matter of fundamental human rights necessitating progressive intervention by the state and civil society in ways that move it beyond an immediate issue of welfare.

Dreze \& Sen (1989) have argued that hunger is a many-headed monster related to a wide range of deprivations: biological, economic and social. While the focus of their studies is global hunger in the developing world it is also important to recognize that First World hunger in the 1990s should be understood both as an attribute of absolute or primary poverty and a key attribute of relative deprivation. In 1899, Rowntree (Townsend, 1979) in his studies of poverty in the UK defined people as living in primary poverty where 'total earnings are insufficient to obtain the minimum necessaries for the maintenance of merely physical efficiency'. A century later this physical concept of need still applies. It means that individuals and families do not have enough money to pay the rent, heat their homes, 
buy clothes, afford transport and generally take care of themselves. As a consequence, as the evidence of the national case studies makes clear, it is the food budget, being the most elastic, which suffers, and individuals and families, including many children, go hungry. The situation is absolute in that hungry people require immediate material and practical assistance without which their physical capacity to lead normal healthy lives and also to survive is threatened. Indeed, even in First World countries, some may die from lack of food as revealed by Wilson (1997) writing about the situation in Australia. Hunger clearly requires prompt and direct responses, but its day-to-day alleviation is related to a range of other issues such as unemployment, inadequate housing and sub-poverty level welfare benefits, which governments today refuse to acknowledge.

Clearly, a broader approach to the problem of hunger is required and, following Townsend (1979), we should understand it in terms of a social conception of need or as a consequence of 'relative deprivation' where people lack the resources to obtain the types of diets, participate in the activities and have the living conditions and amenities which are customary or at least widely encouraged or approved in the societies to which they belong. Their resources are so seriously below those commanded by the average individual or family that they are, in effect, excluded from ordinary living patterns, customs and activities (Townsend, 1979).

In other words, people's experience of hunger and poverty is directly related to the societies in which they live and the standards of living which are customarily enjoyed. If the citizens of affluent industrialized countries cannot afford to purchase food in the supermarket or local corner store, and are dependent on intermittent food-bank handouts, whilst they may still be better nourished than hungry people in the developing world, they are still hungry. Moreover, their experience of having to obtain food in such a humiliating way is personally undermining and stigmatizing. From this perspective hunger must be understood as a function of inequality.

Another useful framework for thinking about hunger is that of the concept of food security (Radimer et al. 1992). Hunger is 'the inability to acquire or consume an adequate quality or sufficient quantity of food in socially acceptable ways, or the uncertainty that one will be able to do so' (Radimer et al. 1992). This operational definition is derived from a study of low-income women in upstate New York as part of a nutrition surveillance project to develop more precise indicators of hunger experienced by women and children. The women described hunger existing at two levels: the individual and the household, and each level comprised quantitative, qualitative, psychological and social components. At the individual level the responses of the women were labelled as insufficient food intake, nutritional inadequacy, lack of choice and feelings of deprivation and disrupted eating patterns; at the household level the problems were those of food depletion, unsuitable food, anxiety about the food supply and having to acquire food in socially unacceptable ways (Radimer et al. 1992). Hunger, therefore, was not only being without food but being unable to acquire it through normal channels. It was experienced as a 'managed process' in which the women adopted a range of coping mechanisms in their attempt to keep hunger at bay. Hunger provoked anxiety and uncertainty about where the next meal was coming from. In other words, the central issue for the women of upstate New York, as for millions of hungry people elsewhere, was one of food security.

In 1983, the United Nations defined the goal of food security as being 'to give populations both economic and physical access to a supply of food, sufficient in both quality and quantity, at all times, regardless of climate or harvests, social level or income' (Food and Agriculture Organization, 1995). This definition, whilst comprehensive, appears to rely on an assumption of aid and charity rather than people having control over their 
food production and distribution systems. A more empowering definition is that provided by the Ontario Public Health Association (1995), which states that the challenge of food security is when people 'can get enough food to eat that is safe, that they like to eat and that helps them to be healthy. They must be able to get this food in ways that make them feel good about themselves and their families'. Achieving food security should be a central goal of public policy and should engage questions not only of critical welfare policy and social security reform, but of basic human rights, community health, food policy, agricultural reform, community development and local control of food supply.

It should also be noted that the United Nations (UN; 1994) recognizes that the overall availability of food in the world is not a problem... 'there is enough food to offer everyone in the world around 2500 calories $(10.4 \mathrm{MJ})$ a day-200 calories $(0.8 \mathrm{MJ})$ more than the basic minimum'. If that is the case, it is essential that we understand hunger primarily as a political issue. If it is to be eliminated in First World countries, to say nothing of its abolition in developing countries, the roots of hunger must be acknowledged to be man-made (the term is used advisedly). As Fernand Braudel (1985), the eminent French historian, once said, 'Today's society, unlike yesterday's is capable of feeding its poor. To do otherwise is an error of government'. Hunger is a basic human need and people everywhere have an inalienable right to adequate nutritious food.

\section{HUNGER: ITS INCIDENCE AND NATURE}

Evidence about hunger in the national case studies derives from direct and indirect indicators and anecdotal sources. Direct indicators refer primarily to hunger surveys and prevalence studies and clinical studies of malnutrition; indirect evidence is based on the existence of emergency feeding programmes, including food banks and soup kitchens, school meal programmes, inferential data from dietary studies, welfare benefit statistics, poverty lines and unemployment data, the adequacy of welfare benefits and public opinion surveys. Anecdotal descriptions of hunger and of the issues confronting those providing and receiving emergency food assistance have also been included by a number of the authors.

Whilst there are reasonable grounds for caution in terms of the reliability and validity of much of the indirect data, particularly that of food-bank usage and the problems of double counting, the evidence for the existence of hunger is compelling when understood within the context of each country's high rates of poverty, unemployment and underemployment. More to the point, perhaps, if legitimate criticisms can be made of the data on hunger it is also necessary to be aware of the ways in which governments are prone to manipulate official data. For example in the UK, Craig \& Dowler (1997) noted that in the early 1980 s the government introduced twenty-nine measures in which official counts of unemployed were altered, thereby considerably reducing the official unemployment count.

The incidence of hunger revealed in the national case studies is considerable. Poppendieck (1997), noting varying estimates of hunger in the USA, reports a 1991 figure of twenty-eight million hungry people derived from poverty-line data and reported by the Tufts University Center on Hunger, Poverty and Nutrition Policy (Center on Hunger, 1993, 1995) as well as the finding of a major survey undertaken on behalf of Second Harvest (Van Amburg Group, 1994), the National Food Bank Network, which estimates 21.8 million people (based on unduplicated count) receiving emergency food in 1994. Poppendieck (1997) also notes that for the first 3 months of 1994 average monthly participation in the Food Stamp Programme reached a record high of 27.8 million persons. In Canada, evidence of hunger began to appear in the early 1980 s with the emergence of 
food banks, and the estimate of 2.5 million people ( $8.6 \%$ of the population) turning to these emergency food outlets in 1994 seems reasonable in light of a national poverty rate of $17 \%$ in 1993 (Riches, 1997). Food banks also helped highlight the issue in New Zealand, although, as Uttley (1997) notes, it was not until the 1990s that hunger and access to food became established on the political agenda. National food-bank data are not available in New Zealand, although the distribution of the Salvation Army's food parcels alone rose from 1226 in 1990 to 14906 in 1994. Similarly, in Australia, Wilson (1997) observes that whilst benchmark studies do not exist, the experience of hunger is widespread and the demand for emergency relief increased in the early 1990s. Between 1990 and 1992 one in eight Australian households were estimated to be living below the poverty line. In the UK, Craig \& Dowler (1997) suggest that the existence of hunger can be inferred from the statistical information on welfare benefits and they quote from the 1994 study by the National Children's Home (1994) report that 'over 1.5 million families in Britain could not afford to feed their children an 1876 workhouse diet at present Income Support levels'. Moreover, Craig \& Dowler (1997) note that 'there is much concern in medical and some government circles that members of poor UK households are more likely to be ill, to die in infancy, or at an early age when adult, than those in richer households'.

\section{THE CAUSES OF HUNGER}

While there are undoubtedly unique and specific reasons for the growth of hunger in each of the five 'liberal' welfare states, certain explanations are supported by each of the national case studies. Two categories of explanation suggest themselves: one has to do with changing economic conditions and the adequacy of welfare programmes in the face of the magnitude of the problems, while the other reflects the responses of the state and civil society to the health and welfare needs, including that of hunger, of increasing numbers of people. As each of the studies demonstrates, there can be little doubt that hunger is an outcome of prolonged high rates of unemployment and under-employment, growing inequality in terms of wealth distribution, and the declining value of real wages and welfare benefits or the purchasing power of households. These factors are directly related to massive economic restructuring generated by the forces of market globalization and the pursuit by nation-states of economic growth, and increased international competitiveness through committing themselves to anti-inflation and deficit-reduction policies, free trade and labour-market deregulation and social-spending cutbacks. As the individual case studies show, this 'new right' economic agenda has been pursued with varying degrees of application in each country, but always at the expense of secure and protected jobs and livelihoods, and always on the backs of the most vulnerable. Massive unemployment since the beginning of the 1980 s has placed tremendous pressures on unemployment insurance and public assistance programmes which, it must be recognized, were originally designed as short-term stopgaps.

The evidence is also unequivocal in its condemnation of inadequate welfare benefits being the immediate cause of hunger. The fact is that in none of the countries studied is it possible to provide for a nutritionally-adequate diet on the basis of social assistance incomes alone. Whilst there is evidence from the UK to suggest that those seeking to manage on welfare incomes are efficient managers of their food budgets, the unassailable fact is that when food expenditures have to be weighted against the increasing price of rent, utilities, clothing and other essentials it is the food bill which invariably suffers. Healthy eating, which means access to nutritious food and to a varied diet, as Craig \& Dowler (1997) note, is expensive. 
In addition, state-supported supplementary welfare programmes intended to provide emergency support and discretionary lump-sum payments for those with special needs are also failing. Government-provided emergency assistance in Australia often runs out before the year's end; eligibility criteria for the discretionary payments of the Social Fund in Britain, where emergency loans can be obtained, are difficult to meet; in New Zealand, the policies for claiming special benefits are so complex that not even the social security staff understand them; in the US food-stamp benefits are inadequate for providing adequate nourishment and food assistance programmes have been cut back; and in Canada, as in the other countries, public welfare officials frequently refer clients to charitable food banks, a clear sign that the right to the guaranteed social minimum is an illusion and that the public safety net is in tatters.

\section{RESPONSES OF THE STATE AND CIVIL SOCIETY}

It must be emphasized that none of the countries studied suffers from an under-supply of food. All of these societies are food-producing exporting countries and import additional requirements. Hunger is primarily an issue of distributional justice engaging broad questions of work and income distribution, food policy, agricultural practices, health and welfare reforms, nutrition education, charitable aid, community development and the role of the state and the community sector. Hunger is essentially a political question and one which demands a committed response both by the state and civil society. Yet as the evidence shows government has largely refused to respond to the issue and community action, despite a number of progressive non-governmental organization (NGO) initiatives, has been divided and barely effective.

First, in terms of welfare policy the record is not good. Neo-liberal welfare-reform strategies, informed by the structural adjustment policies promoted by international institutions such as the World Bank, the International Monetary Fund and the Organization for Economic Co-operation and Development have been widely adopted in each country as a means to reduce both social spending and welfare dependency by encouraging and frequently coercing those in receipt of social assistance to re-enter the labour market. 'Workfare' (i.e. welfare policy which requires all claimants to undertake work or training as a condition of receiving benefit) and less eligibility (the idea that no-one on welfare should receive more than the lowest-paid wage earner) have taken centre-stage in the reform of public welfare. The problem, of course, is that there are insufficient well-paying jobs to absorb the numbers of unemployed people, particularly when governments are looking to private, not public, investment to create the necessary employment. The welfare recipe on offer is principally designed to manage large-scale unemployment by attaching stringent conditions to the receipt of welfare and by coercing people into lowwage work thereby disciplining labour and exerting downward pressure on wage demands. Welfare reform has resulted in increased targeting of services, cuts to benefits and the capping of social expenditures. It has also been a story of off-loading welfare responsibilities from national and federal governments to lower levels of government, of developing partnerships with churches and the voluntary sector, and insisting that individuals and families, which of course, means women, once again, will have to pick up the burden.

Second, the state has responded to the problem of hunger by denying its existence, by neglecting its legislated and public responsibilities, by framing the issue of welfare costs in terms of fraud and abuse and by blaming the victim. In New Zealand, the official response has been to deny a causal link between government policy and food-security problems, to 
blame child hunger on poor parenting and to press the case that governments and the voluntary section should work together on the issue (Uttley, 1997); the UK government attempted to turn aside criticisms about the extent of child begging and sleeping on the streets made by the UN committee monitoring the Convention on the Rights of the Child (United Nations, 1989, 1990) by suggesting that the UN turn its attention to Brazil where 'real' poverty existed (Craig \& Dowler, 1997); in Canada, the Mulroney government similarly sought to dismiss criticisms of reduced welfare support for the poor made by the UN committee monitoring the International Covenant of Economic, Social and Cultural Rights (United Nations, 1966) by claiming that its research was flimsy and inadequate (Riches, 1997); in Australia, there is government denial of the need to address hunger and undernutrition as a genuine priority, as the main issue is seen to be that of overconsumption (Wilson, 1997); in the USA, general welfare has been abolished in Illinois and Michigan and, as in Canada, the federal government is cutting welfare funding and shifting responsibility for public welfare programmes back to the states, thereby undermining national standards and rights to benefits (Poppendieck, 1997).

Third, there is some evidence that the public health sector in the majority of the countries, at least since the World Declaration on Nutrition (Food and Agriculture Organization, 1992) has begun to take an interest in hunger and undernutrition. In 1993, New Zealand's Public Health Commission argued for the adoption of the UN definition of food security, reasoning that the elimination of poverty depends on the purchasing power of households (Uttley, 1997); however, in Australia, according to the Australian Institute of Health and Welfare (1994), undernutrition is believed to be uncommon (Wilson, 1997). In the UK the national Nutrition Task Force established a Low Income Project Team in 1994 to address the dietary problems of low-income people (Williams \& Dowler, 1994; Craig \& Dowler, 1997). Community food security is emerging as an important policy goal in the USA. Community health initiatives are being developed at the local and municipal level (Poppendieck, 1997). In Canada, similar developments are occurring in the community health sector. Yet it must be recognized that in none of the countries studied is there evidence of political commitment to promoting co-ordinated national food policies which effectively link the knowledge and expertise of health, welfare, agriculture, etc.

Fourth, despite such indications that the public health sector is more active in pursuing the issue of hunger than their welfare counterparts, it would appear that there is a cynical attempt by governments in the international arena to demonstrate a commitment to uphold basic human rights, while at the same time undermining commitments to food security at home. With the exception of the US, each of the countries in the study are signatories to the International Covenant on Economic, Social and Cultural Rights (United Nations, 1966) and the UN Convention on the Rights of the Child (United Nations, 1989, 1990), both of which commit ratifying governments to meet the basic needs of their citizens. Each society has also committed itself to achieving the goals set out in the World Declaration on Nutrition (Food and Agriculture Organization, 1992) and those of the World Summit for Social Development (United Nations, 1995a) and its commitment to eradicate poverty. Yet, for example, in Canada, whilst the federal government proclaims the right of its poorest citizens to adequate food, clothing and shelter in international law, it has recently (April 1996) repealed the Canada Assistance Plan, thereby stripping social assistance claimants of these very rights.

It is not difficult, therefore, to believe that officially there is a cynical and deliberate attempt to jettison the idea of a guaranteed social minimum and right to food security, and instead reassert the commodified notion that a person's welfare is entirely conditional on her or his ability to participate in the labour market. Given the incapacity of the economy to 
generate the necessary jobs and adequate incomes this approach to welfare reform, as the lessons of history show, can only result in increased hunger and deprivation. The only response, therefore, for government committed to neo-conservative welfare reform, and its rejection of the idea of social and economic rights, is publicly to deny the hunger its policies are creating and to do whatever they can to depoliticize it as an issue. Unfortunately, they are frequently aided in this process by the voluntary community.

Last, it should be stated that while community responses to hunger have been impressive, they contain troubling dilemmas and contradictions. There can be little doubt that for many people the assistance provided by charitable food banks and emergency feeding programmes has kept hunger at bay and that their presence serves as a constant reminder that food insecurity is a critical public issue. In each country studied it can be seen that they are an important expression of community altruism, yet despite the work of food banks and other front-line feeding agencies the evidence of different countries confirms that they are not solving the problem of hunger. Far from being an emergency response they have become an institutionalized extension of a failing public welfare system. Governments refer their clients to them and food-bank parcels are factored into the calculation of welfare benefits. Yet food banks cannot guarantee that hunger will be met: they are subject to donor fatigue and run out of food, they cannot necessarily provide nutritious or culturally-appropriate food, they depend on volunteers who cannot always be counted upon and people's experience of having to ask for charity is often degrading and stigmatizing. More problematic is the effect which food banks have on community attitudes; they allow us to believe that the problem is being met and they deflect attention away from government and its legislated responsibilities. They serve to undermine social and economic rights. In this sense they play a key role in the depoliticization of hunger as a public issue, particularly when they enlist the services of the media to support them in the food drives. In this way the media come to portray hunger and the work of food banks as just another charitable cause. This is precisely what government wishes to hear and it helps them promote their argument that it is only in partnership with the community that the hunger problem can be solved.

Essentially it is a story of increasing hunger and unacceptable hardships, inadequate benefits and punitive welfare policies, government denial and uncoordinated public policy and valiant but inadequate charitable and community responses. More profoundly, it is a story of the failure of the 'liberal' welfare state and the principle of the commodification of social rights and welfare entitlements.

\section{ADVANCING FOOD SECURITY: EMERGING STRATEGIES}

The key goal in addressing hunger should be to establish the right of food security for all. The national case studies suggest five broad approaches: understanding the nature of the hunger problem and the forces which oppose its resolution; creating long-term policy goals which focus on the structural preconditions of hunger; mobilizing for public action; devising both short-and long-term strategic objectives for working within and against the system.

If the problem of hunger in wealthy and technologically-advanced countries is to be eliminated, it must be recognized first, that hunger is essentially a political question and a fundamental issue of human rights and distributive justice. In recent years hunger has been caused by massive economic restructuring, rising unemployment, and poverty, growing inequality and the impact of 'new right' economic ideology on political decision-making. The state has pursued a range of labour market and welfare reform policies which have led 
to increased pauperization, and in so doing has turned its back on the poor and hungry. Whilst there have been some positive developments in the community health sector and by voluntary and charitable agencies in terms of providing emergency assistance, these efforts have not been sufficient to stem the growth of hunger. Moreover, in a contradictory manner food-bank activity has assisted the state in eroding people's rights and entitlements to basic welfare assistance and has aided the depoliticization of the hunger issue. Any strategy which seeks to eliminate hunger and establish a right to food security must, therefore, acknowledge the failure of current policies and practices.

Comprehensive policies need to be developed, not just by anti-poverty advocates, health and welfare experts and proponents of sustainable agriculture but also by those who have to date been on the receiving end of charity. The debate about the right to food security will need to consider what it means for individual households, local communities, national society and within the global context. Rights to food security must be justiciable (i.e. welfare claimants have, or should have, the right, enforceable in law, to receive adequate state financial assistance or welfare benefits). In other words, there must be legal remedies at hand if people are deprived by the state of the right to adequate food allowances and to other necessities such as shelter and clothing.

Sustainable economic welfare which puts the needs and rights of vulnerable people (and environments) ahead of profit maximization suggests a way ahead. Elements of a comprehensive strategy should include commitments by the state to adequate incomes and welfare benefits irrespective of one's formal employment status, full employment (redefined in terms of promoting socially-useful work as well as the right freely to choose one's work), progressive taxation policies which effectively redress the balance between personal and corporate taxation, imposition of the Tobin tax on the financial transaction of international money markets, universal health- and child-care and effectively co-ordinated national and local approaches to progressive agricultural food and nutrition policies.

A more specific food and nutrition strategy could well look to the ideas of the Ontario Public Health Association (1995) and its policy objectives of equal access to food, a sustainable food supply, and the promotion of food for health which are discussed in greater detail in the Canadian case study (Riches, 1997). Community control of the food supply and distribution system, greater access to farmers' markets, community kitchens and food co-operatives, more effective nutrition education, sustainable agricultural practices and the requirement of high nutritional standards in situations of mass catering are important aspects of this approach. Food self-reliance is a key objective of these proposals. If hunger and undernutrition are a function of people's lack of control over the food production and distribution system, then it is essential that empowerment strategies are developed in order to reassert ownership. Community development and locally-based solutions are fundamental to the process of change.

In order to advance the debate about people's right to food security and the elimination of hunger, the role of public action must be considered. As Uttley (1997) observes in the New Zealand case study, Dreze \& Sen (1989) provide a useful framework for thinking about public action, not just as government intervention and the public delivery of services (which is, of course, essential), but as public participation, both in terms of collaborative and adversarial processes. In other words, NGO and civil society need to support governments in their initiatives to resolve the hunger problem, but at the same time must also challenge inappropriate policies and advocate progressive alternatives. This implies working within the system and outside it.

In the short term, public action should focus on developing new forms of service with and for people who are hungry, seek to educate the public on why the problem of hunger 
exists and cooperate with governments at all levels in working to create effective national plans for nutrition and food security and the promotion of progressive welfare policies. This may be easier said than done, but often the local or municipal level of government is responsive to ideas about 'community health' promotion and this provides a useful way to enter the debate not just about policy but about practical responses to the hunger problem.

Adversarial action will also be necessary in terms of continuing to name the issue of hunger, in advocating with and on behalf of those who have had their benefits cut or who are homeless and hungry. Challenges will need to be mounted at the local level concerning the inappropriateness of welfare reform and work will need to be undertaken with likeminded welfare advocacy groups such as those representing women, labour, people with disabilities and immigrant and indigenous people's organizations. It will also be necessary to make effective links between the welfare, health, agriculture, environmental and development education sectors and ensure that those organizations that represent and speak on behalf of low-income people are centrally involved in the debate. International aid organizations and domestic food banks and food policy councils need to work together. Building effective anti-hunger coalitions is likely to prove difficult, particularly in terms of moving beyond the politics of difference which has so shaped the struggle for human rights in the post-modern era. Yet in both the short term and long term, if universal basic needs such as hunger and poverty are to be recognized and addressed, coalition-building by progressive organizations will be an inevitable condition for successful public action.

In the longer term, collaborative strategies should continue to focus on working with governments on the development of a comprehensive policy framework. Useful starting points are the World Declaration on Nutrition (United Nations, 1992) and the Global Assembly on Food Security (Food and Agriculture Organization, 1995) as well as the commitments of governments to address the issues arising from the World Summit for Social Development (United Nations, 1995a) and the Fourth World Conference on Women in Beijing (United Nations, 1995b). The fact that the UN has declared 1996 to be the International Year for the Eradication of Poverty provides an important context for the development of progressive initiatives, as does the UN's World Food Summit being held in Rome in late 1996. Collaboration will also require educating not only the public but also the media as to the real causes of hunger and the consequences for society if the issue is left unaddressed.

In terms of challenging and contesting public policies which undermine the right to food security over the longer term the issues will undoubtedly prove difficult. One important mechanism for asserting the right to adequate food lies in international covenants which governments have ratified and public action should focus on making national, state and provincial governments accountable in terms of international law. Despite the fact that, as the Canadian (Riches, 1997) and UK (Craig \& Dowler, 1997) case studies show, governments will object to the international monitoring of their welfare policies, the opportunity exists for citizens' groups to raise the issue of social and economic rights with the UN monitoring committees. This could prove to be an important tool for maintaining public pressure and for requiring government accountability. In fact, it could prove to be a significant tool for organizing at the local level as it provides a politically-useful way for educating people about human-rights issues in both a local and global context. In the context of federal jurisdictions, state and provincial governments can also be held accountable for complying with international law.

Perhaps the essential question which must be addressed if hunger and absolute poverty are to be eliminated in the First World is whether the liberal welfare state regimes of 
Australia, Canada, New Zealand, the UK and the USA can recognize the social and economic rights of people to basic standards of living, free from the requirement that benefits must always be attached to labour-force participation. This is a particularly significant question given the inability of these societies to generate sufficient well-paying jobs. How possible is it to reject less eligibility and 'workfare' and move beyond the commodification of social and economic rights? The signs are not hopeful in that the "new right' economic agenda seems installed for a long time to come and given the forces of market globalization, it is difficult to see how the economic, social and environmental agenda can be reclaimed. Yet there is room for optimism. The social democratic Scandinavian welfare states have shown that hunger need not exist. Indeed, the growing awareness in the international and domestic NGO and community sector that hunger and poverty in 'advanced' and 'developing' countries are interrelated issues, and ones which require intersectoral analysis and collaboration if they are to be eliminated, is significant. It can only be hoped that the UN International Year for the Elimination of Poverty and the World Food Summit in 1996 create a positive context for progressive reform and advance.

\section{REFERENCES}

Australian Institute of Health and Welfare (1994). Australia's Health 1994. 4th Biennial Health Report of the Australian Institute of Health and Welfare. Canberra: Australian Government Publication Service.

Braudel, F. (1985). The 'New History'. World Press Review 32, 30-32.

Bread for the World Institute (1995). Hunger 1995: Causes of Hunger. Fifth Annual Report on the State of World Hunger. Silver Springs, MD: Bread for the World Institute.

Center on Hunger (1993). Summary of U.S. Hunger Estimates: 1984 to the Present. Center on Hunger, Poverty and Nutrition Policy. Medford: Tufts University.

Center on Hunger (1995). Statement on Key Welfare Reform Issues: Empirical Evidence. Medford: Tufts University.

Craig, G. \& Dowler, E. (1997). Let them eat cake: poverty, hunger and the UK state. In First World Hunger: Food Security and Welfare Politics, [G. Riches, editor]. London: Macmillan.

Dreze, J. \& Sen, A. (1989). Hunger and Public Action. Oxford: Clarendon Press.

Esping-Andersen, G. (1990). The Three Worlds of Welfare Capitalism. Cambridge: Polity Press.

Food and Agriculture Organization (1992). World Declaration on Nutrition. Rome: FAO.

Food and Agriculture Organization (1995). Food Security: Still Far From the Goal. Rome: FAO.

National Children's Home (1994). The Workhouse Diet. London: National Children's Home.

Ontario Public Health Association (1995). Food for Now and the Future; A Food and Nutrition Strategy for Ontario. Discussion Paper of the Food Security Work Group. Toronto: Ontario Public Health Association.

Poppendieck, J. (1997). The USA: hunger in the land of plenty. In First World Hunger: Food Security and Welfare Politics, [G. Riches, editor]. London: Macmillan.

Radimer, K. L., Olson, C. M., Green, J. C., Campbell, C. C. \& Habicht, J. P. (1992). Understanding hunger and developing indicators to assess it in women and children. Journal of Nutrition Education 24, Suppl., $36 \mathrm{~S}-45 \mathrm{~S}$.

Riches, G. (editor) (1997). Hunger in Canada: abandoning the right to food. In First World Hunger: Food Security and Welfare Politics. London: Macmillan.

Townsend, P. (1979). Poverty in the United Kingdom. Harmondsworth: Penguin.

United Nations (1966). International Covenant on Economic, Social and Cultural Rights. General Assembly Resolution 2200A (XX1). New York: UN.

United Nations (1989). UN Monitoring Committee on the Convention of the Rights of the Child. New York: UN.

United Nations (1990). Convention of the Rights of the Child. Information Kit. New York: Centre for Human Rights.

United Nations (1994). United Nations Development Programme. Human Development Report 1994. New York: Oxford University Press.

United Nations (1995a). World Summit for Social Development. Copenhagen Declaration and Programme of Action. Copenhagen: UN.

United Nations (1995b). Fourth World Conference on Women. Beijing Declaration and Platform for Action. Beijing: UN.

Uttley, S. (1997). Hunger in New Zealand: a question of rights. In First World Hunger: Food Security and Welfare Politics, [G. Riches, editor]. London: Macmillan. 
Van Amburg Group (1994). Second Harvest 1993 National Research Study, revised ed. Erie, PA: Van Amberg Group Inc.

Williams, C. \& Dowler, E. (1994). Identifying Successful Projects on Diet and Low Incomes: A Review of the Issues. Working Paper no. I for the Low Income Project Group Team to the Nutrition Task Force. London: Department of Health.

Wilson, J. (1997). Australia: lucky country/hungry silence. In First World Hunger: Food Security and Welfare Politics, [G. Riches, editor]. London: Macmillan. 